\title{
MORPHOLOGY OF THE STERNAL GLANDS OF POLISTES FUSCATUS AND P. CANADENSIS
} (HYMENOPTERA: VESPIDAE)*

\author{
By David C. Post and Robert L. Jeanne \\ Department of Entomology \\ University of Wisconsin-Madison \\ Madison, Wisconsin 53706
}

\begin{abstract}
Although 13 exocrine glands have been located in wasps of the genus Polistes, and 12 in Mischocyttarus (Landolt and Akre, 1979), their morphology and functions have been little studied. Recently, however, the sternal gland on the sixth gastral (terminal) segment of females of these wasps has attracted attention because its secretion is repugnant to some species of ants. Female wasps rub the secretion onto the nest petiole, thus forming a chemical barrier against predatory ants (Jeanne, 1970; Hermann and Dirks, 1974; Turillazzi and Ugolini, 1978, 1979; Post, 1980).

Close to the anterior margin of the sternite is a hyaline area covered with a tuft of long hairs ('sternal brush') (van der Vecht, 1968). In Polistes a cluster of gland cells underlies the cuticle on each side of the sternal brush (Landolt and Akre, 1979; Turillazzi, 1979). Ducts lead from the gland cells to the cuticular surface within the sternal brush. A smaller number of gland cells also occurs in a band along the anterior margin of the fifth gastral sternite (Hermann and Dirks, 1974; Turillazzi, 1979).

We undertook the present study to determine the presence of these glands in Polistes fuscatus (F.), a temperate zone species, and in $P$. canadensis (L.), a tropical species, and to compare the size and morphology of the glands in these species with those in congeners previously investigated by Hermann and Dirks (1974) and Turillazzi (1979)
\end{abstract}

\section{Materials AND MethodS}

Adult female foundresses and workers of $P$. fuscatus (F.) were collected in Madison, Wisconsin, on 13 June, 2 and 21 July, and 9 September, 1978. Adult $P$. canadensis canadensis (L.) were collected

\footnotetext{
*Manuscript received by the editor July 3, 1980.
} 
at Taperinha, near Santarém, Pará, Brazil $\left(2^{\circ} 32^{\prime} \mathrm{S}, 54^{\circ} 20^{\prime} \mathrm{W}\right)$ on 13 November 1978. P. canadensis specimens were collected from both pre- and post-emergence nests. After fixing the wasps in Kahle's solution, the sternites and attached tissue were removed and embedded in Spurr Low-Viscosity embedding media (Polysciences) following the methods of Spurr (1969). Sections $2 \mu$ thick were cut with a glass knife on a Porter-Blum-Ultra-Microtome MT-1 (Sorvall ${ }^{\circledR}$ ) for examination with the light microscope. Staining was with Mallory's Azure II-Methylene Blue (Richardson et al., 1960).

For SEM preparations specimens were dehydrated in $100 \%$ ethanol and sonified. After air drying the tissues were coated with a thin layer of gold-palladium and examined with a JELCO JSM-U3 scanning electron microscope at $20 \mathrm{kV}$. Images were recorded on Polaroid film (Type 55, P/N).

Adult females of each species were dissected in order to estimate the number of gland cells in the terminal sternite. The number of cells in each gland was estimated by determining the length and width of the glandular mass by means of a filar micrometer eyepiece, dividing each by $0.025 \mathrm{~mm}$ (approximate diameter of an individual gland cell), multiplying the two results and then multiplying by the thickness of the gland, in numbers of gland cells (determined from histological sections) (1.25 for $P$. fuscatus and 2.5 for $P$. canadensis). Although this estimate does not give an exact count of the number of gland cells, it does allow a comparison of the relative number of gland cells in the two species.

\section{RESULTS}

\section{6th Sternite.}

As in species studied previously, the anterior region of the terminal sternite of female $P$. fuscatus and $P$. canadensis bears a brush-like arrangement of dense hairs (Figs. $1 \& 2$ ). The brush is denser and more extensive in $P$. canadensis than in P. fuscatus. The cuticle underlying the brush is lightly sclerotized and translucent (hyaline), but is not thinner than adjacent cuticle. The gland consists of two clusters of glandular cells (class 3 cells of Noirot and Quennedey, 1974), one on each side of the brush and hyaline area; there are no gland cells directly beneath the brush (Fig. 3). Each gland cell is connected by a duct to the sternal surface (Figs. $4 \& 5$ ). The majority of the ducts run mesad from the gland cells to the brush (Fig. 6) and 

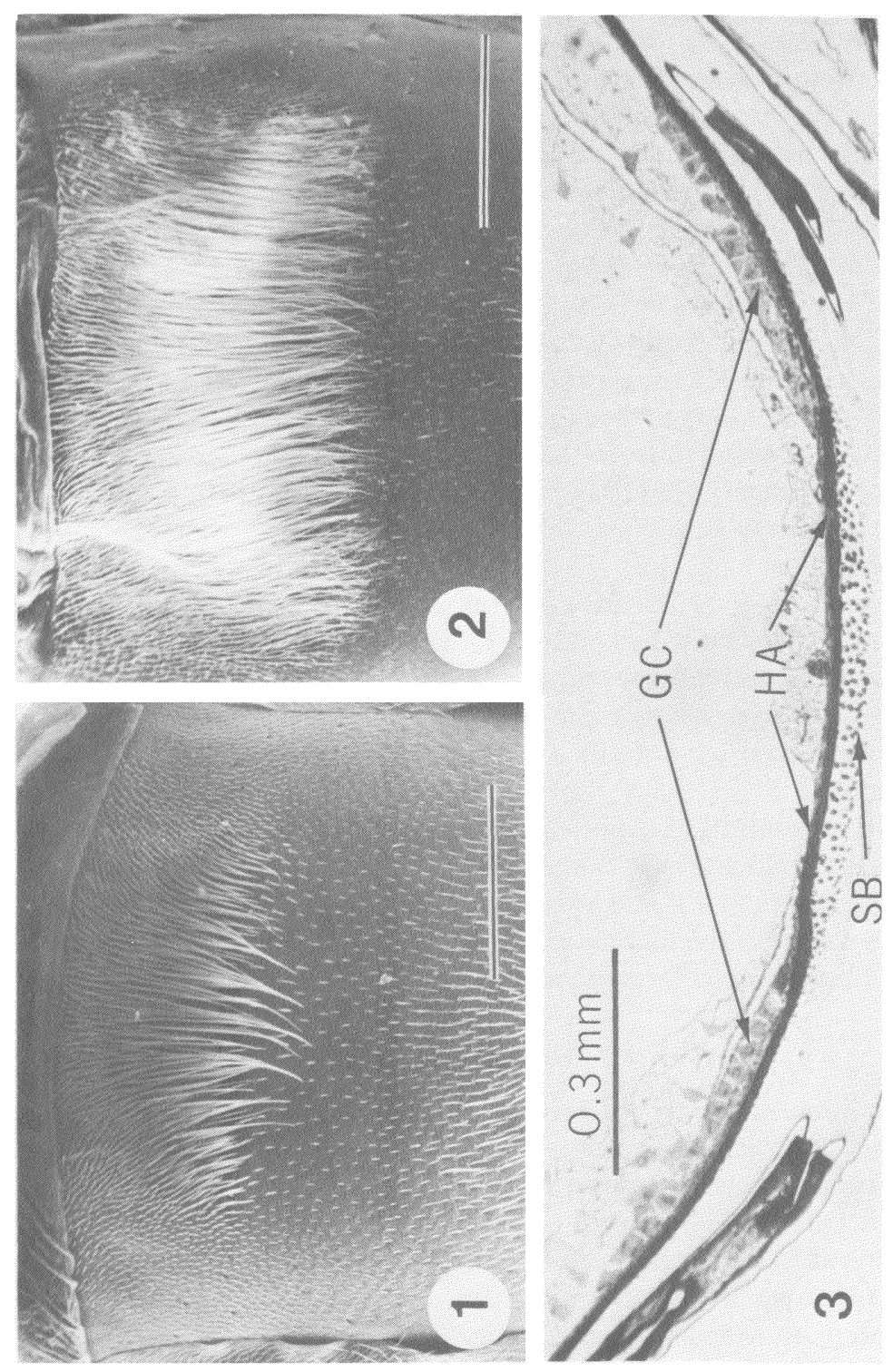

岕造葛

ن

$\leftrightarrows 0^{\circ}$

总赑

है

區㤩

$\because \dot{0}$

\%

II

ชี

is

ป

งั

م. $11 \frac{\pi}{00}$

琎

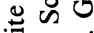

昰产

สี

कू हैं

类

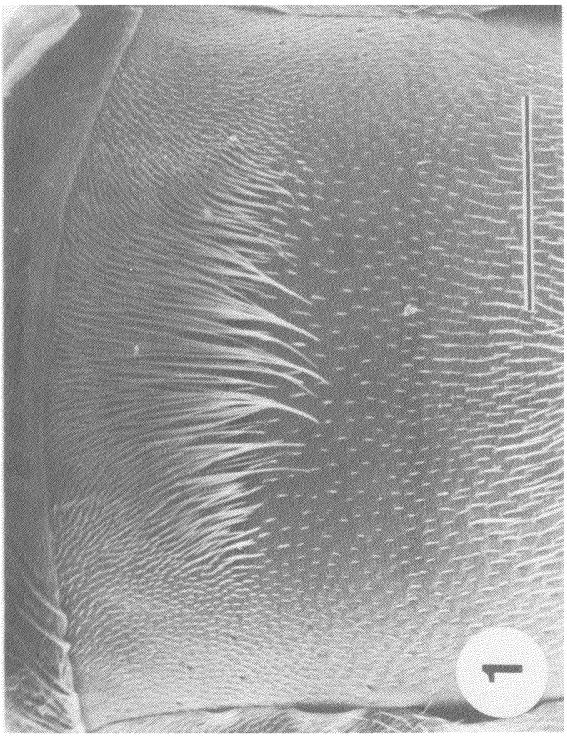

क्षे

壱

造

点焉

两

跣

के

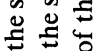

范

동 동

营

융

동

$\sum$

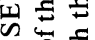

듀응

녹

玨造递 
empty through the cuticle between the hairs (Fig. 5). A few ducts do not run to the brush, but empty through the cuticle lying directly over the gland cells (Fig. 4). In both species each mass of gland cells is enclosed by a thin basement membrane or lamella (Fig. 6).

The gland is larger in P. canadensis than in P. fuscatus (Figs. $7 \& 8$ ). Each cluster of cells contains approximately 1676 cells ( 2 specimens) (56-105 cells per section; 4 specimens) in $P$. canadensis and 597 cells (3 specimens) (18-38 cells per section; 6 specimens) in $P$. fuscatus.

The epithelium underlying the class 3 cells is thickened by the elongation of the epidermal cells, suggesting that these are secretory cells (class 1 cells of Noirot and Quennedey, 1974) (Figs. 4, 7, 8). This epithelium is thicker in P. canadensis ( $\overline{\mathrm{x}}=34.0 \mu ; 3$ specimens) than in P. fuscatus ( $\overline{\mathrm{x}}=15.5 \mu, 6$ specimens). Epidermal cells not underlying the class 3 cells, including those in the hyaline area, are flattened and irregular in appearance (unmodified) in both P. canadensis $(\overline{\mathrm{x}}=6.4 \mu$; 3 specimens) and $P$. fuscatus ( $\overline{\mathrm{x}}=5.8 \mu ; 6$ specimens).

5th Sternite.

The anterior margin of the fifth gastral sternite of both species bears a narrow band of class 3 gland cells, although a brush is lacking. Histological sections revealed fewer gland cells in P. canadensis (4-8 cells per section; 4 specimens) than in $P$. fuscatus (10-15 cells per section; 6 specimens) (Figs. $9 \& 10$ ). The gland cells are enclosed by a basement lamella.

As on the sixth sternite, the epithelium lying under the class 3 cells is thickened, and is thicker in $P$. canadensis ( $\overline{\mathrm{x}}=39.1 \mu ; 3$ specimens) than in P. fuscatus ( $\overline{\mathrm{x}}=7.8 \mu ; 3$ specimens) (Figs. $9 \& 10$ ).

There were no detectable individual differences in gland morphology or development in either species.

\section{Discussion}

Our most important new finding is that the epidermal cells associated with the class 3 gland cells on both sternites are modified into what appear to be class 1 gland cells in both species. The reason Hermann and Dirks (1974) did not observe this in P. annularis (L.) may be attributed to their use of late pupae instead of adults. These cells may not become elongated until active.

A second point on which $P$. fuscatus and $P$. canadensis apparently differ from what Hermann and Dirks (1974) report for P. annularis is that the class 3 cells of sternite 6 clearly form two clusters that lie to 

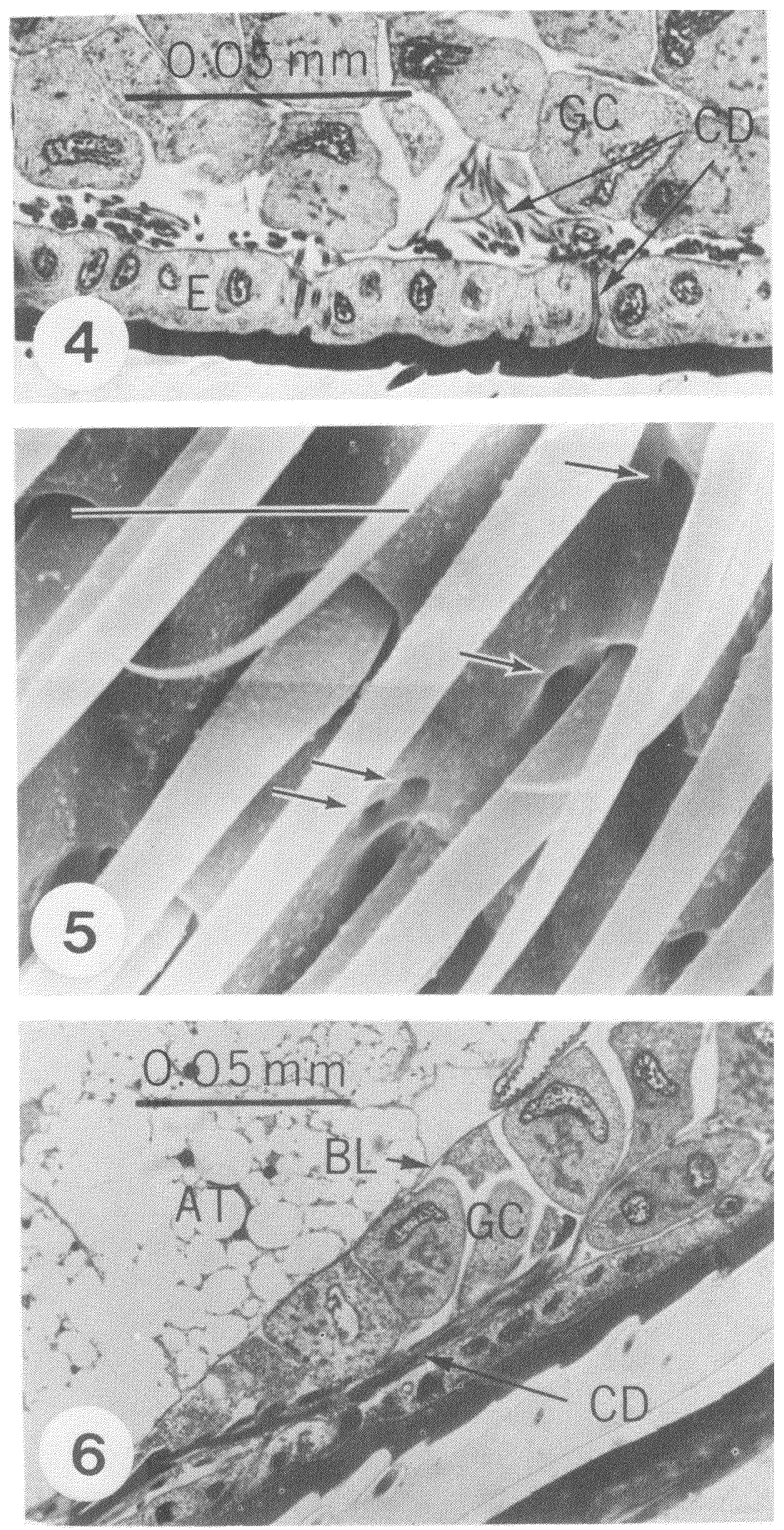

Figure 4. Longitudinal section ( $2 \mu$ thick) through the glandular area of the sixth gastral sternite of $P$. canadensis. $\mathrm{GC}=$ glandular cells; $\mathrm{E}=$ epidermis; $\mathrm{CD}=$ glandular cell ducts. Figure 5. SEM photograph of the glandular cell duct openings (indicated by arrows) at the base of the sternal brush hairs of $P$. fuscatus. Anterior is to the upper right. Scale $=0.05 \mathrm{~mm}$. Figure 6 . Transverse section $(2 \mu$ thick) through the glandular area of the sixth gastral sternite of $P$. fuscatus. Midline is to the left. $\mathrm{GC}=$ glandular cells; $\mathrm{AT}=$ adipose tissue; $\mathrm{CD}=$ glandular cell ducts; $\mathrm{BL}=$ basement lamella. 


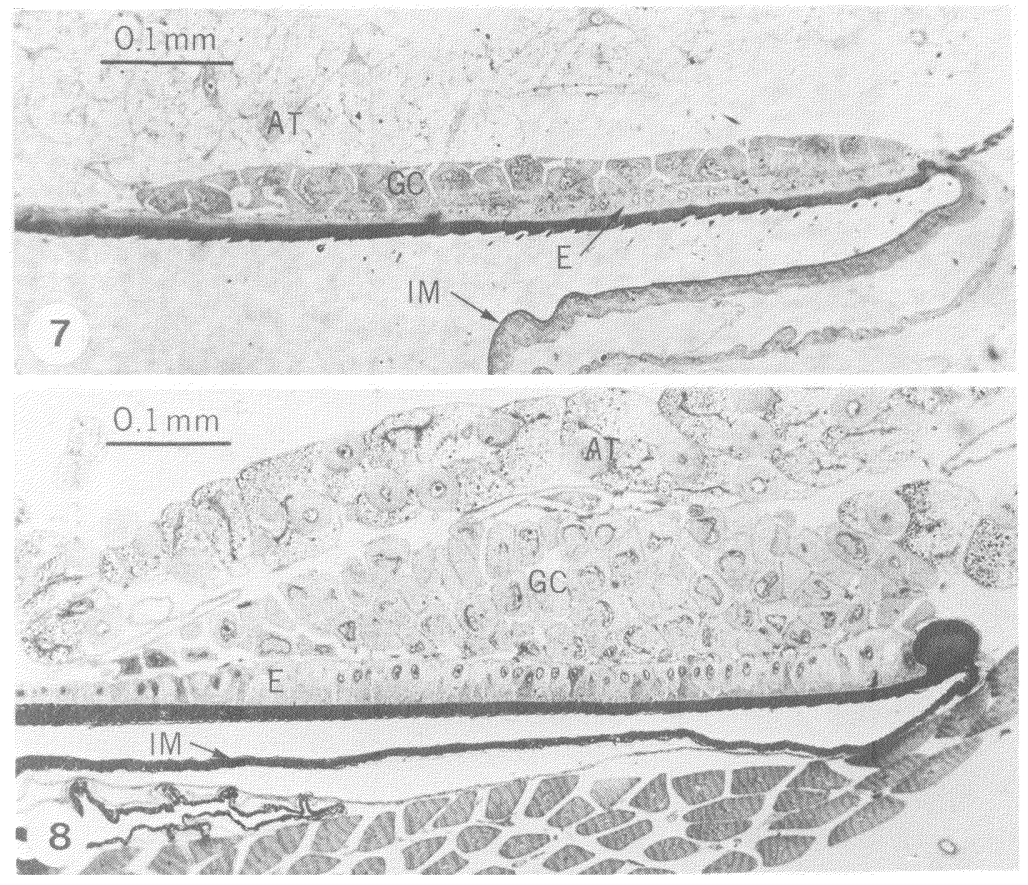

Figure 7. Longitudinal section ( $2 \mu$ thick) through the glandular area of the sixth gastral sternite of $P$. fuscatus. Anterior is to the right. $\mathrm{GC}=$ glandular cells; $\mathrm{E}=$ epidermis; $\mathrm{IM}=$ intersegmental membrane; $\mathrm{AT}=$ adipose tissue. Figure 8 . Longitudinal section ( $2 \mu$ thick) through the glandular area of the sixth gastral sternite of $P$. canadensis. Anterior is to the right. $\mathrm{GC}=$ glandular cells; $\mathrm{E}=$ epidermis; $\mathrm{IM}=$ intersegmental membrane; $\mathrm{AT}=$ adipose tissue.

the sides of the hyaline area and brush. Hermann and Dirks state that gland cells "extend beneath most of the integumental surface upon which the sternal brush is found" (p. 6), although their figures do not document this statement. Turillazzi (1979) showed clearly that in $P$. gallicus (L.) and P. foederatus (Kohl) the class 3 gland cells of sternite 6 form two lateral clusters.

Hermann and Dirks (1974) found that the class 3 cells in $P$. annularis pupae were close packed and polygonal. Landolt and Akre (1979) argued that this is the undeveloped condition, and that the cells of active adult glands are globose. Our sections of active adult glands of $P$. fuscatus and P. canadensis clearly show these cells to be 
close packed and polygonal and bounded by a membrane. The discrepancy may be an artifact of the techniques used in each study. Hermann and Dirks (1974) sectioned fixed and embedded material, as we did, while Landolt and Akre (1979) dissected fixed specimens. It is possible that during dissection they may have ruptured the membrane enclosing the gland cells, allowing them to float free at the ends of their ducts and assume a spheroid form. On the other hand, it is possible that the difference is taxonomic. We have found that the class 3 cells on the fifth sternite of females of Polybia (Polistinae: Polybiini) are globose and apparently not bounded by a membrane, even in histological sections (Jeanne and Post, in preparation). It is not clear whether Landolt and Akre meant to generalize their statement to all genera they studied (Vespula, Dolichovespula, Vespa, Polistes, and Mischocyttarus) or just to Vespula and Dolichovespula.

If the columnar epithelial cells associated with the ducted class 3 cells on the sixth sternite are indeed producing an exocrine secretion, it is not clear what its function could be. Even though this secretion would reach the cuticular surface to the side of the brush, it could well be applied to the nest petiole along with the product of the class 3 cells. Whether there it serves as a component of the ant repellent or has some other function is unknown. Alternatively, if it is volatile, it could evaporate from the cuticular surface, in which case its function is less likely to be involved with defense against ants.

The fact that $P$. canadensis has approximately three times as many class 3 cells on sternite 6 as does $P$. fuscatus is consistent with the hypothesis that these cells produce the ant repellent that is applied to the nest petiole. Since ant predation pressure is higher in the tropics than temperate regions (Jeanne, 1979), one way P. canadensis, a tropical species, could counter this increased threat is by having more gland cells, producing greater amounts of ant repellent secretion. Turillazzi (1979) also found that $P$. gallicus, a species ranging into northern Europe, has fewer class 3 gland cells than does either $P$. omissus (Weyrauch) or P. foederatus, species of southern Europe and Africa (Kemper \& Döhring, 1967). This correlation between gland size and geographic distribution need not, of course, rule out other hypotheses as to the function of the secretion.

The role of the class 3 gland cells on sternite 5 is open to question. It is possible that the secretion has the same function as that of the 6th sternal gland, for, as Turillazzi (1979) points out, it would also be 


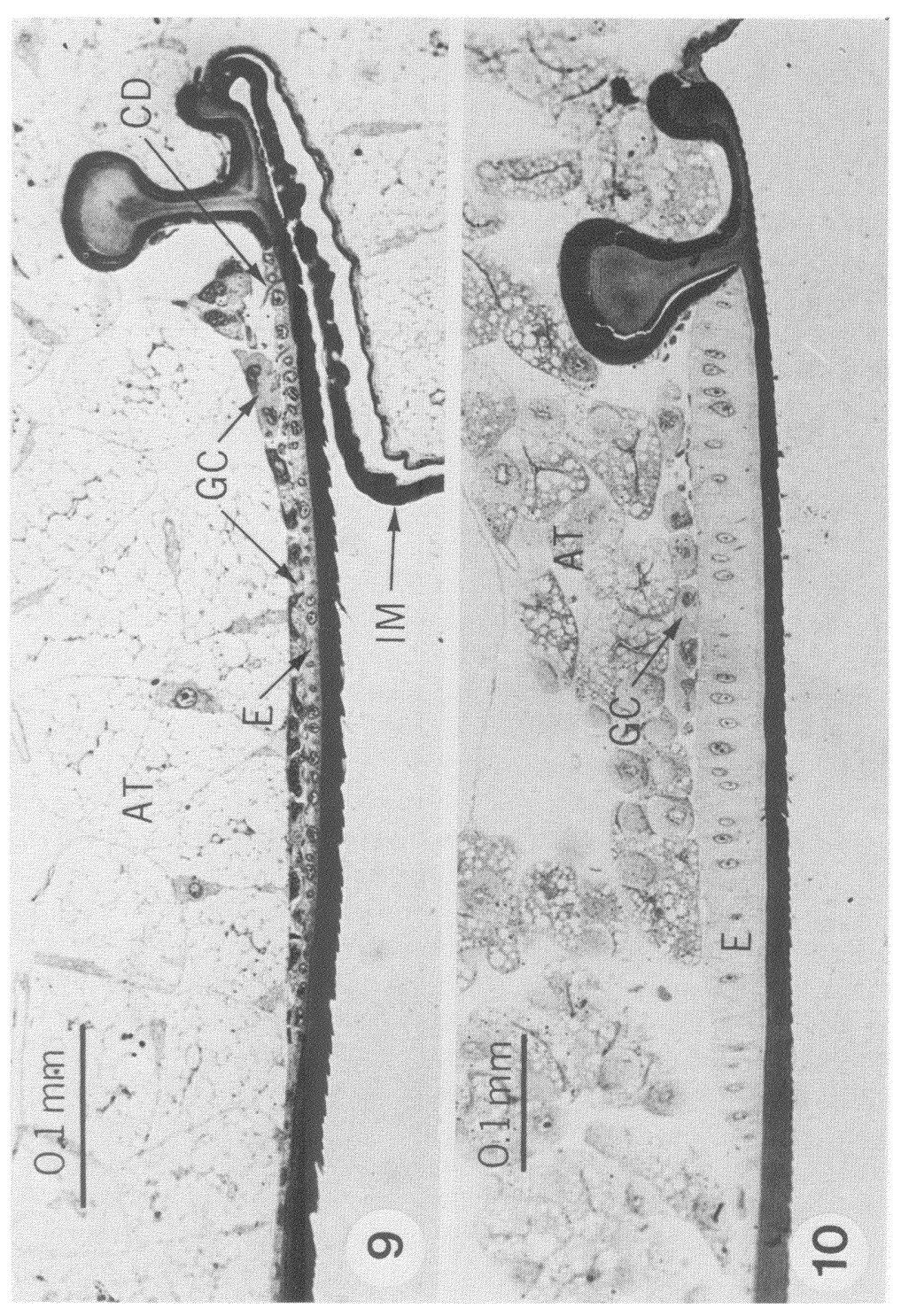


likely to be smeared onto the nest petiole during rubbing. On the other hand, at least three facts could be interpreted as arguments against an identical role: (1) P. fuscatus has more gland cells on the 5 th sternite than does $P$. canadensis, just the reverse of the condition on sternite 6 (although the epidermal cells of this sternite are thicker in $P$. canadensis, suggesting perhaps that they have an independent function); (2) The tuft of long hairs present on sternite 6, where it presumably acts as an applicator brush, is absent from sternite 5; (3) the class 3 gland cells are distributed in a narrow transverse band on sternite 5 , very unlike the two lateral clusters found on sternite 6 .

Although we detected no significant individual differences in gland size or morphology in either species, the ages and castes of our specimens were unknown. A careful EM study correlating degree of glandular activity with age and caste could provide useful insight into the function or functions of these glands.

\section{ACKNOWLEDGMENTS}

B. Jane Harrington provided helpful comments on an earlier draft of this manuscript. Martin Garment provided assistance and advice on scanning electron microscopy. We thank Donas Erica and Violeta Hagmann for their generous hospitality shown us during our stay in Brazil. This research was supported in part by the College of Agricultural and Life Sciences, University of Wisconsin, Madison, and by National Science Foundation Grant BNS-77-04081.

\section{Literature Cited}

Hermann, H.R. and T.F. Dirks

1974. Sternal glands in Polistine wasps: morphology and associated behavior. J. Georgia Entomol. Soc. 9: 1-8.

JEANNE, R.L.

1970. Chemical defense of brood by a social wasp. Science 168: 1465-1466.

1979. A latitudinal gradient in ant predation pressure. Ecology 60: 1211-1224.

KEMPER, H., AND E. DöHRING

1967. Die sozialen Faltenwespen Mitteleuropas. Paul Parey, Berlin. 180 pp.

LANDOLT, P.J. AND R.D. AKRe.

1979. Occurrence and location of exocrine glands in some social Vespidae (Hymenoptera). Ann. Ent. Soc. Am. 72: 141-148.

NoIRot, C. AND A. QUENNEDEY

1974. Fine structure of insect epidermal glands. Ann. Rev. Entomol. 19: 61-80. Post, D.C.

1980. Chemical defense in the temperate social wasp, Polistes fuscatus (Hymenoptera; Vespidae). M.Sc. Thesis, Univ. Wisconsin, Madison. 
RichaRdSON, K.C., L. JARRET AND E.H. Finke

1960. Embedding in epoxy resins for ultrathin sectioning in electron microscopy. Stain Technol. 35: 313-323.

SPURR, A.R.

1969. A low viscosity epoxy resin embedding medium for electron microscopy. J. Ultrastructure Res. 26: 31-43.

TURILlazzI, S.

1979. Tegumental glands in the abdomen of some European Polistes (Hymenoptera: Vespidae). Monitore Zool. Ital. (N.S.) 13: 67-70.

Turillazzi, S. AND A. UgolinI

1978. Nest defense in European Polistes (Hymenoptera: Vespidae). Monitore Zool. Ital. (N.S.) 12: 72.

1979. Rubbing behaviour in some European Polistes (Hymenoptera: Vespidae). Monitore Zool. Ital. (N.S.) 13: 129-142.

Van Der Vecht, J.

1968. The terminal gastral sternite of female and worker social wasps. Proc. K. ned. Akad. Wet. (C) 71: 411-422. 

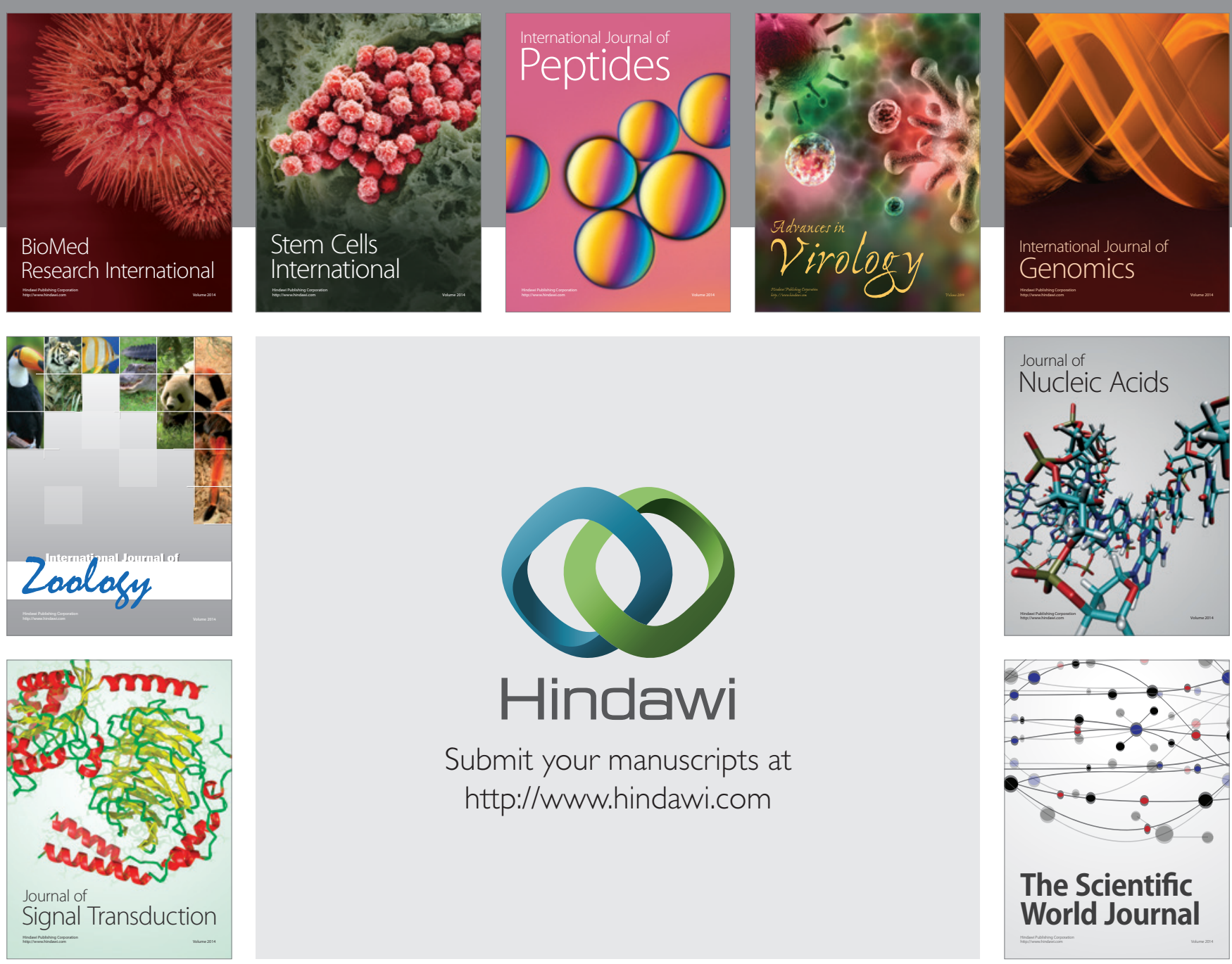

Submit your manuscripts at

http://www.hindawi.com
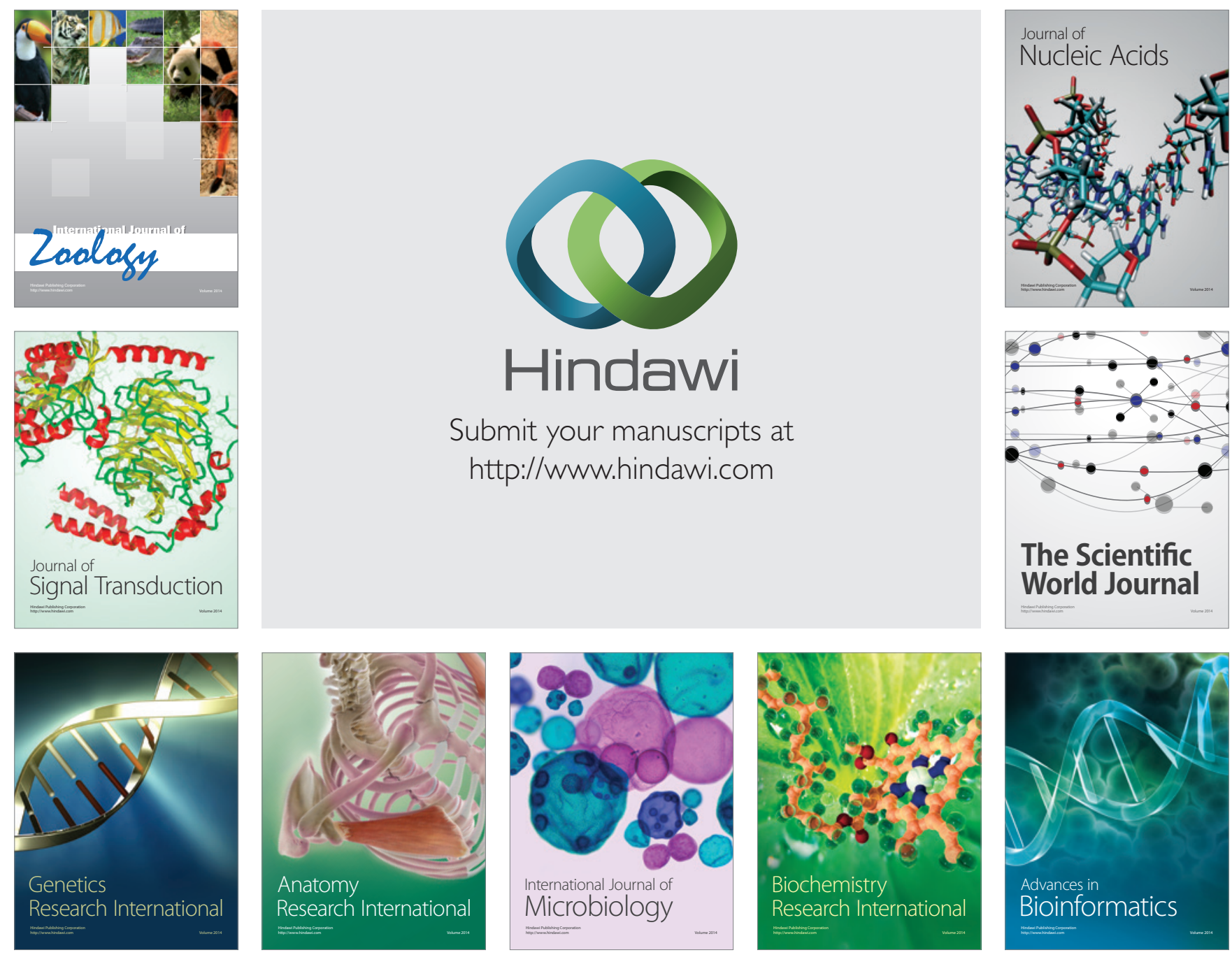

The Scientific World Journal
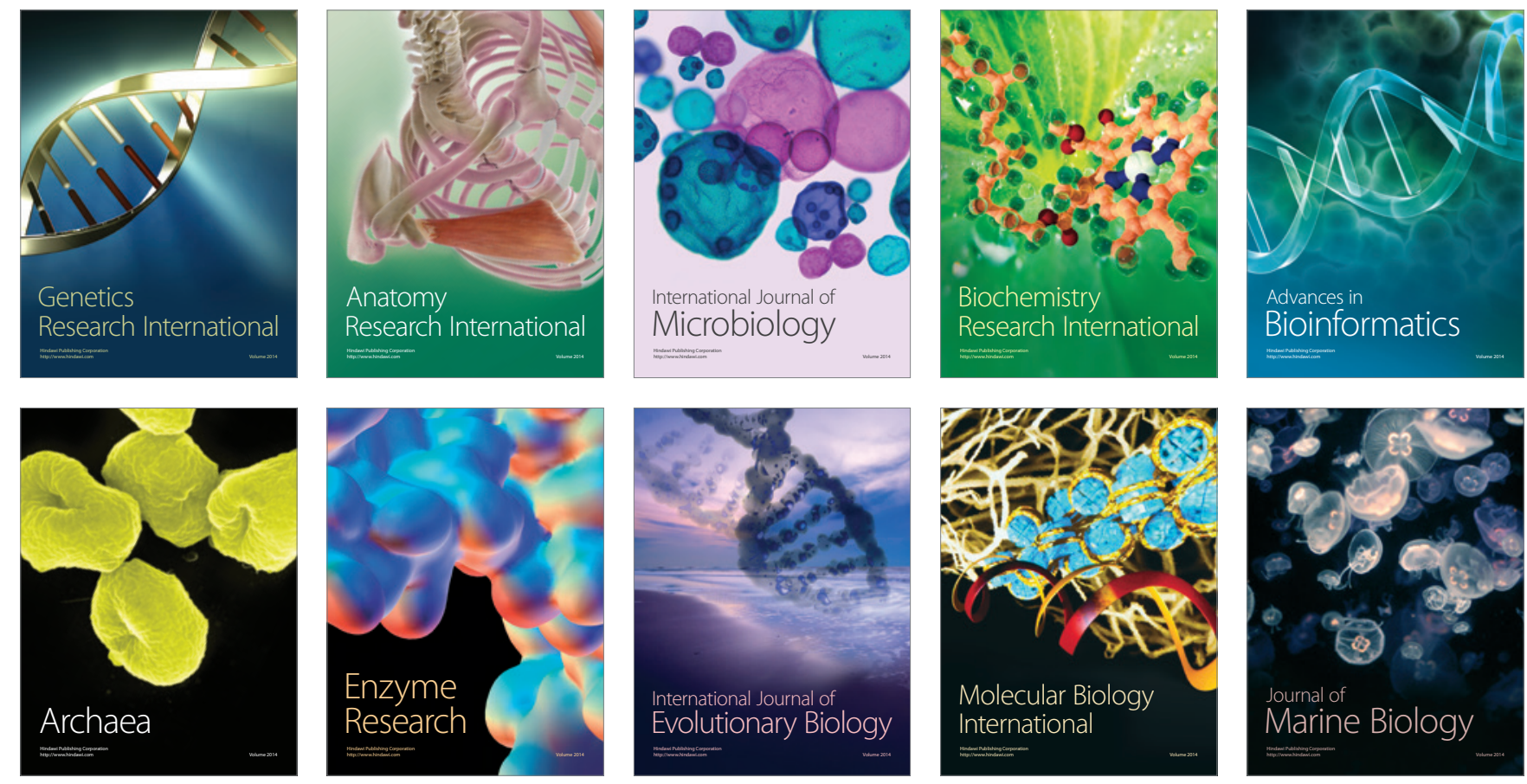